\title{
Abnormalities of factor VIII related protein multimers in the haemolytic uraemic syndrome
}

\author{
P E ROSE, S M ENAYAT, R SUNDERLAND, P E SHORT, C E WILLIAMS, \\ AND F G H HILL \\ Departments of Haematology and Nephrology, Children's Hospital, Birmingham
}

SUMMARY Factor VIII related activities and factor VIII related antigen multimeric analysis have been assessed in two sporadic and eleven epidemic cases of haemolytic uraemic syndrome. In all patients factor VIII related antigen was raised and had an abnormal multimer pattern at presentation. The return to normal of factor VIII related antigen values and multimeric analysis patterns paralleled clinical improvement and, therefore, may be useful in monitoring patients with haemolytic uraemic syndrome. We postulate that endothelial cell damage releases the abnormal high molecular weight factor VIII related antigen multimers and that this may cause platelet agglutination in vivo.

The haemolytic uraemic syndrome is characterised by a prodromal episode of diarrhoea followed by acute renal failure associated with a microangiopathic haemolytic anaemia and thrombocytopenia. ${ }^{1}$ The pathogenesis of the disorder remains unknown but recent suggestions have included abnormalities of platelet-endothelial cell interaction, ${ }^{2}$ with primary endothelial damage by a variety of toxic agents proposed as the initiating step in platelet adhesion, aggregation, and fibrin deposition. ${ }^{3}$ Reduced concentrations of prostacyclin, ${ }^{4}$ a lack of a stimulator of prostacyclin production, ${ }^{5}$ and the presence of an inhibitor of prostacyclin $^{6}$ have also been reported in some patients with this syndrome.

Prostacyclin also influences platelet activity by inhibiting thrombin induced exposure of platelet receptors for the high molecular weight component of the factor VIII complex. ${ }^{7}$ This high molecular weight component, factor VIII related antigen, is reduced or absent in von Willebrand's disease, ${ }^{8}$ whereas the lower molecular weight part of the complex has the active coagulant factor VIII activity that is deficient in haemophilia A. Factor VIII related antigen has a biologically active site known as von Willebrand's factor or ristocetin cofactor, which is required for ristocetin induced platelet aggregation. Von Willebrand's protein (factor VIII related antigen/von Willebrand's factor) consists of a series of multimers of different molecular weight. ${ }^{9}$

Haemolytic uraemic syndrome occurs principally in young children and has been considered similar to thrombotic thrombocytopenic purpura which occurs predominantly in adults. ${ }^{10}$ In chronic relapsing thrombotic thrombocytopenic purpura absence of the high molecular weight multimers has recently been noted during the acute phase of illness and this is thought to be related to platelet agglutination associated with the uptake of the multimers. ${ }^{11}$ During the convalescent stage, these patients showed increased values of high molecular weight factor VIII related antigen multimers. In patients with haemolytic uraemic syndrome, the procoagulant part of the factor VIII complex has been shown to be increased during the acute illness and to return to normal with subsequent clinical improvement. ${ }^{12}$ Factor VIII related antigen has also been reported to be raised with a rapid return to normal values on clinical recovery, ${ }^{13}$ but studies of factor VIII related antigen multimeric composition have only been reported in one child with haemolytic uraemic syndrome. ${ }^{14}$

We have, therefore, measured factor VIII related antigen, von Willebrand's factor, and factor VIII related antigen multimeric composition in 13 children with haemolytic uraemic syndrome (11 cases from the West Midlands 1983 epidemic and two sporadic cases) to see if changes in factor VIII related antigen are implicated in the pathogenesis of haemolytic uraemic syndrome.

\section{Methods}

Patients. Thirteen children with clinical evidence of 
haemolytic uraemic syndrome (microangiopathic anaemia, thrombocytopenia, and acute renal failure) were investigated. All the patients had diarrhoea at presentation. Eleven presented during an epidemic of haemolytic uraemic syndrome in the West Midlands between July and September 1983; the remaining two were sporadic cases also presenting in 1983. The clinical and biochemical features of these patients at presentation are shown in Table 1.

Venous blood was collected by venepuncture and nine volumes added to one volume of $0.11 \mathrm{M}$ trisodium citrate. Platelet poor plasma was prepared by centrifugation at $1500 \mathrm{~g}$ for 15 minutes and stored at $-20^{\circ} \mathrm{C}$ until tested.

Factor VIII related antigen was determined using an enzyme linked immunosorbent assay (ELISA) as described by Short et al. ${ }^{15}$ Von Willebrand's factor was measured by a modification of the method of Brinkhous et $a^{16}$ using paraformaldehyde fixed platelets and ristocetin at a final concentration of 1 $\mathrm{mg} / \mathrm{ml}$. Crossed immunoelectrophoresis of factor VIII related antigen was done as previously described. ${ }^{17}$ As some plasma samples had very high values of factor VIII related antigen, crossed immunoelectrophoresis was also undertaken on samples diluted with buffer to give a final concentration of $1 \mathrm{U} / \mathrm{ml}$. Multimeric analysis of factor VIII related antigen was performed using SDS agaroseacrylamide gel electrophoresis with a discontinuous buffer technique as previously described, ${ }^{18}$ using a modification of the method of Zimmerman and Ruggeri. ${ }^{9}$

\section{Results}

Coagulation studies were performed at diagnosis and thereafter as clinically indicated. A shortening of the partial thromboplastin time by more than three seconds was found in eight of the 13 patients (see Table I). No patient was considered to have acute disseminated intravascular coagulation. All 13 patients had noticeably raised factor VIII related antigen values (range 1.92 to $7.0 \mathrm{U} / \mathrm{ml}$ : mean 3.95 $\mathrm{U} / \mathrm{ml}$; normal range 0.5 to $1.5 \mathrm{U} / \mathrm{ml}$ ) and seven of these were investigated serially during their illness. A rapid fall in factor VIII related antigen was observed in four children at the time of clinical recovery while a persistently raised factor VIII related antigen value was observed over a three week period in two children (see Fig. 1) who have

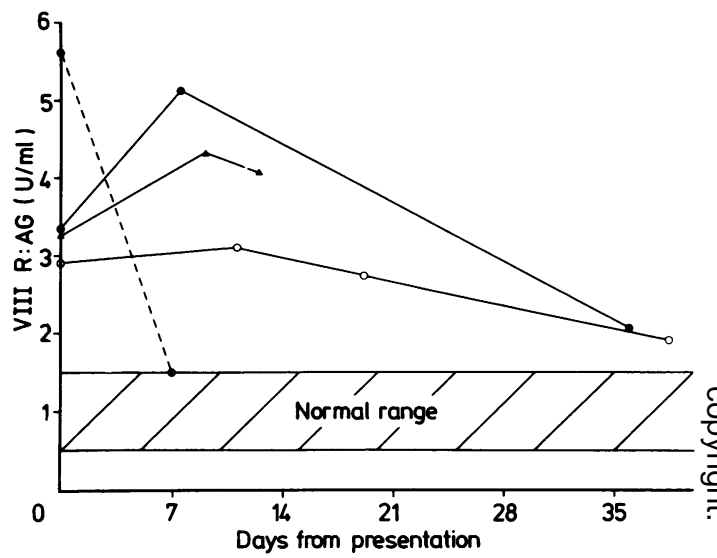

Fig. 1 Serial factor VIII related antigen (VIIIR:AG) values from four patients with haemolytic uraemic syndrome are shown.

Patient $1(--)$ shows a rapid return of VIIIR:AG to normal. Patients $(\mathrm{O}-\mathrm{O})$ and $8(\mathrm{O})$ show persistently raised VIIIR:AG values and both developed chronic renal failure. Patient $3(\Delta-\Delta)$ shows persistently raised VIIIR:AG values and died with neurological complications.

Table 1 Presenting symptoms and biochemistry, renal management and outcome for 11 epidemic and 2 sporadic cases of haemolytic uraemic syndrome

\begin{tabular}{|c|c|c|c|c|c|c|c|c|}
\hline \multirow{2}{*}{$\begin{array}{l}\text { Patient } \\
\text { No }\end{array}$} & \multirow{2}{*}{$\begin{array}{l}\text { Age } \\
\text { (years and } \\
\text { months) }\end{array}$} & \multirow{2}{*}{$\begin{array}{l}\text { Prodromal } \\
\text { illness } \\
\text { (days) }\end{array}$} & \multirow{2}{*}{$\begin{array}{l}\text { Neurological } \\
\text { symptoms }\end{array}$} & \multirow{2}{*}{$\begin{array}{l}\text { Blood pressure } \\
(\mathrm{mm} \mathrm{Hg})\end{array}$} & \multirow{2}{*}{$\begin{array}{l}\text { Plasma } \\
\text { creatinine } \\
(\mu \mathrm{mol} / \mathrm{l})\end{array}$} & \multicolumn{3}{|l|}{ Outcome } \\
\hline & & & & & & $\begin{array}{l}\text { Oliguria } \\
\text { (days) }\end{array}$ & Dialysis & $\begin{array}{l}\text { Clinical } \\
\text { outcome }\end{array}$ \\
\hline 1 & $5^{11 / 12}$ & 9 & None & $120 / 70$ & 1137 & 7 & None & Recovery \\
\hline 2 & $17 / 12$ & 3 & Convulsions & $110 / 75$ & 232 & 28 & $\mathbf{P}$ & CRF \\
\hline 3 & $87 / 12$ & 8 & Clonus & $100 / 76$ & 371 & 28 & $\mathbf{P}$ & Died_neurological problems \\
\hline 4 & $29 / 12$ & 2 & None & $150 / 60$ & 473 & 11 & $\mathbf{P}+\mathbf{H}$ & CRF \\
\hline 5 & $137 / 12$ & 8 & None & $110 / 95$ & 1048 & 3 & None & Recovery \\
\hline 6 & $15 / 12$ & 7 & None & $120 / 75$ & 545 & 1 & None & Recovery \\
\hline 7 & $71 / 12$ & 8 & None & $100 / 76$ & 356 & 0 & None & Recovery \\
\hline $8^{*}$ & $1 \% 12$ & 9 & None & $100 / 60$ & 783 & 7 & $\mathbf{P}$ & Myocarditis/CRF \\
\hline 9 & $6 / 12$ & 5 & None & $90 / 50$ & 120 & 2 & None & Recovery \\
\hline 10 & $23 / 12$ & 4 & Convulsions & $120 / 85$ & 1325 & 9 & $\mathbf{P}$ & Spasticity, diabetes \\
\hline 11 & $13 / 12$ & 19 & None & $115 / 60$ & 249 & 5 & None & Recovery \\
\hline $12^{*}$ & $15 / 12$ & 2 & Convulsions & $90 / 70$ & 267 & 6 & $\mathbf{P}$ & Recovery \\
\hline 13 & $34 / 12$ & 1 & Convulsions & $130 / 100$ & 357 & 11 & $\mathbf{P}$ & Recovery \\
\hline
\end{tabular}

*Sporadic cases; $\mathrm{P}=$ peritoneal dialysis; $\mathrm{H}=$ haemodialysis; $\mathrm{CRF}=$ chronic renal failure. 
both developed chronic renal failure. One of these patients (patient 8 , see Table 2) had a good clinical response after seven days with her creatinine concentration falling from 783 to $316 \mu \mathrm{mol} / \mathrm{l}(8.8$ to 3.6 $\mathrm{mg} / 100 \mathrm{ml}$ ), but when dialysis was not performed on the eighth day, she developed acute pulmonary oedema and the creatinine concentration rose again. On that day the factor VIII related antigen value had risen from 3.44 to $5.12 \mathrm{U} / \mathrm{ml}$. Patient 3 (see Fig. 1) who developed neurological complications on the day of hospital admission, with episodes of clonus and extensor spasms, had persistently raised factor VIII related antigen values over a three week period. This patient subsequently died from respiratory problems after a prolonged period of opisthotonus.

Von Willebrand's factor was measured in 13 patients during the acute illness (range 1.0 to 3.3 $\mathrm{U} / \mathrm{ml}$, mean $1.9 \mathrm{U} / \mathrm{ml}$, normal range 0.5 to 1.5 $\mathrm{U} / \mathrm{ml}$ ). The ratio of factor VIII related antigen/von Willebrand's factor was abnormally raised in all patients (range 1.36 to 4.5 , mean 2.32 , normal range $\sim 1)$.

Qualitative abnormalities of plasma factor VIII related antigen were assessed initially with crossed immunoelectrophoresis. Fig. 2 shows the asymmetrical normal arc for comparison with the precipitin arc pattern observed in plasma from some of the patients (patients 2 to 6,10 , and 13). The patients' precipitin arcs have abnormal pre-peaks and increased anodal migration (Fig. 2 and Table 2); additionally, some had double humped peaks (patients 2 and 5). As many of the patients had raised factor VIII related antigen values, the test plasma was diluted in buffer to a final concentration of $1 \mathrm{U} / \mathrm{ml}$ to exclude raised factor VIII related antigen concentration as a cause of the pre-peak. In plasma from five patients (patients 3, 4, 7, 9, and 13) the pre-peak resolved after dilution. All the patients' plasmas contained high molecular weight factor VIII related antigen which migrated poorly under the standard electrophoretic conditions. The pattern of the most anodal component of factor VIII related antigen precipitin arcs also suggests that abnormal amounts of high molecular weight factor VIII related antigen are present in the patients' plasma. Patient 2 was studied serially and these results (Fig. 2) show an increased amount of high molecular weight factor VIII related antigen in the initial samples studied, with a progressive return to a more normal pattern over 30 days.

Factor VIII related antigen multimeric analysis profiles for patients 1, 2, and 4 are shown in Fig. 3. The plasma from these patients, like normal plasma, contains high, intermediate, and low molecular weight multimers of factor VIII related antigen. All the patients' plasmas (like those shown in Fig. 3) showed a normal triplet configuration in the lower molecular weight multimers. In contrast, however, to normal plasma, all the patients' plasmas at presentation showed a trailing effect above the upper limit of normal high molecular weight multimers (see Fig. 3), indicating the presence of multimers of higher molecular weight than those seen in

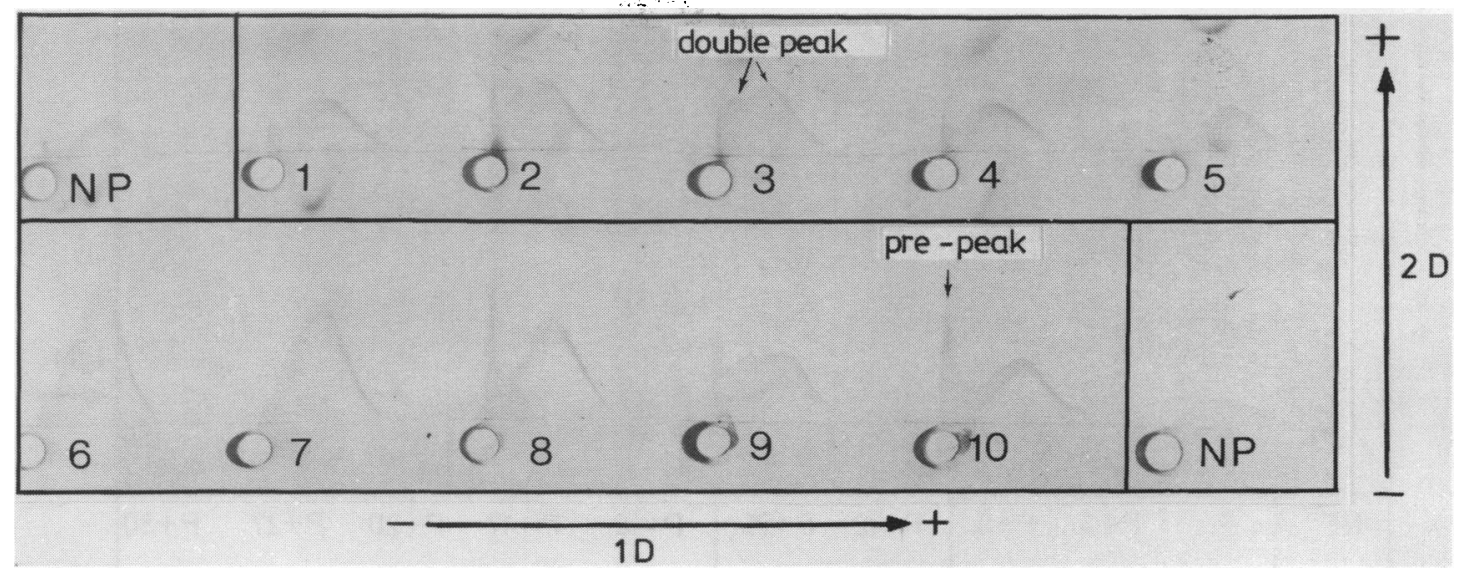

Fig. 2 Crossed immunoelectrophoretic pattern of plasma factor VIII related antigen (VIIIR:AG) from 7 patients with haemolytic uraemic syndrome.

Note (i) pre-peaks for plasmas in wells 1 to 4 and 8 to 10, (ii) double peaks for plasmas in wells 3 and 9 . These abnormal precipitin ares are on plasmas taken during the acute stage of the illness and contrast with the normal arc (NP) and that in well 5 of a patient's (patient 13) plasma after full recovery. Plasma samples electrophoresed in wells $1,8,9$, and 10 are during the acute illness from patients $4,10,5$, and 6 respectively (see Table 1 ); in wells 2,3 , and 4 from patient $2-20$. 27 , and 30 days after presentation; in wells 6 and 7 from patient $3-13$ and 14 days after presentation. 
1138 Rose, Enayat, Sunderland, Short, Williams, and Hill

Table 2 Presenting haematology, coagulation studies, and quantitative assessment of factor VIII related antigen (VIIIR:AG)/von Willebrand factor (VIIIR:WF)

\begin{tabular}{|c|c|c|c|c|c|c|c|c|c|}
\hline $\begin{array}{l}\text { Patient } \\
\text { No }\end{array}$ & $\begin{array}{l}H b \\
(g / d l)\end{array}$ & $\begin{array}{l}P T \\
\text { (sec) }\end{array}$ & $\begin{array}{l}\text { PTT } \\
\text { (sec) }\end{array}$ & $\begin{array}{l}\text { Platelets } \\
\left(\times 10^{9} / 1\right)\end{array}$ & $\begin{array}{l}\text { FDPs } \\
(m g / l)\end{array}$ & $\begin{array}{l}\text { VIIIR:AG } \\
(U / m l)\end{array}$ & $\begin{array}{l}\text { VIIIR:WF } \\
(U / m l)\end{array}$ & $\begin{array}{l}\text { VIIIR:AGI } \\
\text { VIIIR:WF }\end{array}$ & $\begin{array}{l}\text { Migration } \\
\text { index }\end{array}$ \\
\hline 1 & 9.4 & 12 & 22 & 105 & $<10$ & $5 \cdot 60$ & 1.24 & $4 \cdot 5$ & 1.4 \\
\hline 3 & $8 \cdot 0$ & 35 & $>120 \ddagger$ & 57 & - & $3 \cdot 44$ & $1 \cdot 10$ & $3 \cdot 10$ & 0.9 \\
\hline 4 & $7 \cdot 9$ & 12 & 24 & 320 & - & $4 \cdot 70$ & 1.72 & $2 \cdot 7$ & $1 \cdot 1$ \\
\hline 5 & $9 \cdot 1$ & 13 & 26 & 77 & 20 & $4 \cdot 20$ & $1 \cdot 10$ & 3.8 & $1 \cdot 2$ \\
\hline 6 & 5.4 & 17 & 26 & 80 & 20 & $4 \cdot 70$ & $2 \cdot 48$ & 1.89 & $1 \cdot 1$ \\
\hline $8^{*}$ & $8 \cdot 0$ & 16 & 26 & 107 & $<10$ & 3.44 & $2 \cdot 40$ & 1.43 & $1 \cdot 2$ \\
\hline 9 & $11 \cdot 5$ & 13 & 26 & 92 & - & $4 \cdot 60$ & $2 \cdot 40$ & 1.90 & $1 \cdot 1$ \\
\hline 10 & $10 \cdot 2$ & 32 & 32 & 125 & - & $7 \cdot 00$ & $3 \cdot 30$ & $2 \cdot 12$ & 1.0 \\
\hline 11 & 6.4 & 13 & 24 & 45 & - & $3 \cdot 60$ & $2 \cdot 80$ & 1.50 & $1 \cdot 2$ \\
\hline $12^{*}$ & $11.9+$ & 14 & 30 & 55 & 40 & 1.92 & $1 \cdot 24$ & 1.40 & $1 \cdot 2$ \\
\hline 13 & 8.4 & 13 & 22 & 45 & 20 & $2 \cdot 00$ & $1 \cdot 00$ & $2 \cdot 00$ & $1 \cdot 2$ \\
\hline Normal & & 13 & 30 & $>150$ & $<10$ & $0.5-1 \cdot 5$ & $0.5-1 \cdot 5$ & 1.00 & 1.0 \\
\hline
\end{tabular}

"Sporadic cases; tsubsequently became anaemic; łon heparin.

Blood film appearances: fragmented red cells in all; spherocytes in patients $1,2,3,9,10$, and 13 .

PT=prothrombin time; PPT=partial thromboplastin time; FDPs=fibrin degradation products

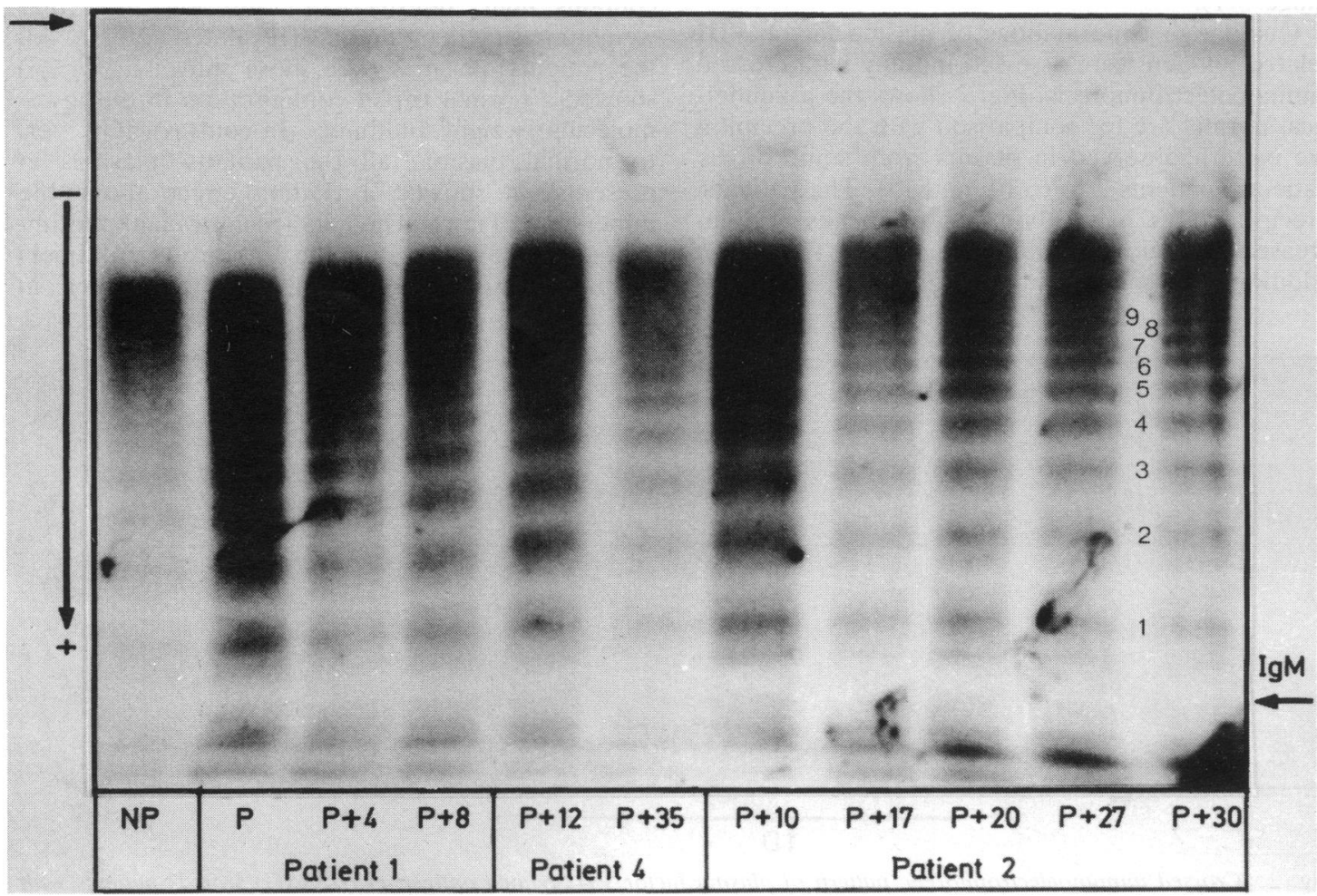

Fig. 3 Factor VIII related antigen (VIIIR:AG) multimeric patterns for normal plasma (NP) and serial samples from 3 patients with haemolytic uraemic syndrome (nos 1, 4, and 2, see Table 1).

$\mathbf{P}$ indicates presentation sample while the figure after $\mathbf{P}+$ indicates days from diagnosis. Note that at diagnosis (in patient 1$)$ and in the earliest samples shown from patients 4 and 2 , that there are increased amounts of all multimeric forms compared with later samples. 
normal plasma. This accords with the pre-peak and abnormal anodal component seen in the crossed immunoelectrophoretic precipitin arcs. Clinical improvement was accompanied by a corresponding fall in these abnormally high and the normal-high molecular weight multimers. In patient 3 , however, persistently increased high molecular weight multimers (not shown) were observed over a three week period before his death.

\section{Discussion}

There are similarities between haemolytic uraemic syndrome and thrombotic thrombocytopenic purpura-a diffuse disease affecting the microcirculation, characterised by microangiopathic haemolytic anaemia, thrombocytopenia, fluctuating neurological abnormalities and, in over $50 \%$ of cases, renal dysfunction. ${ }^{19}$ In some patients with thrombotic thrombocytopenic purpura a spontaneous aggregating agent has been detected. This effect can be inhibited by normal plasma and does not require thromboxane $A_{2}$, release of platelet granule content, platelet metabolism, or calcium or magnesium ions and is, therefore, analogous to in vitro ristocetin induced platelet agglutination. ${ }^{20}$ The latter is accompanied by the attachment to platelets of the large factor VIII related antigen multimers.

In patients with thrombotic thrombocytopenic purpura the absence of the high molecular weight multimers in the early stages and their reappearance with clinical improvement has been taken as evidence that the factor VIII related antigen multimers are involved in the pathogenesis of thrombotic thrombocytopenic purpura. ${ }^{\text {Th }}$ The abnormal high molecular weight multimers are similar to those seen in cultured endothelial cells, ${ }^{21}$ hence Moake et al have postulated that patients with this disease have a defect in processing the large factor VIII related antigen multimers secreted by endothelial cells, and that these abnormal multimers cause periodic relapses. ${ }^{11}$ These authors have reported (unfortunately only in abstract) ${ }^{14}$ two adult cases and one child with haemolytic uraemic syndrome in whom they found similar changes to those in their patients with thrombotic thrombocytopenic purpura. In this small series they postulate that haemolytic uraemic syndrome is a selective but reversible renal endothelial cell defect with associated factor VIII related antigen/von Willebrand's factor platelet aggregation.

Factor VIII related antigen/von Willebrand's factor is required for platelet subendothelial interaction. The former is synthesised in endothelial cells and is present in high concentration in renal endothelium. ${ }^{22}$ Endothelial damage by toxins or immune complexes may result in its release. This factor VIII related antigen may be qualitively abnormal with increased amounts of high molecular weight multimers as observed in factor VIII related antigen from cultured endothelial cells. ${ }^{21}$

In all 13 patients with haemolytic uraemic syndrome we have studied there was a qualitative abnormality of factor VIII related antigen/von Willebrand's factor by both crossed immunoelectrophoresis and multimeric analysis. There was also an increase in the concentration of the high molecular factor VIII related antigen/von Willebrand's factor multimers. The patients in this study were referred and diagnosed after variable periods of prodromal illness but all had abnormally high factor VIII related antigen/von Willebrand's factor multimers in their plasma. This contrasts with the observations of Moake et al in their patients with thrombotic thrombocytopenic purpura and haemolytic uraemic syndrome. ${ }^{11} 14$ In our patients, clinical improvement was associated with a fall in factor VIII related antigen/von Willebrand's factor and normalisation of the abnormal presenting ratio and multimer patterns. The abnormalities persisted, however, in those with progressive renal disease or recurred in those who relapsed.

Because of the findings in our patients we postulate that in haemolytic uraemic syndrome it is endothelial cell damage that causes release of factor VIII related antigen/von Willebrand's factor which has a multimer pattern that is different from that found in normal plasma. Persistence of these abnormal forms reflects continuing endothelial cell damage and a possible secondary effect is that the abnormal multimers cause platelet agglutination to the exposed subendothelium.

In this group, the quantitative and qualitative changes in factor VIII related antigen/von Willebrand's factor parallelled their clinical course. Measurement of factor VIII related activities would seem to be a useful prognostic indicator of the course of haemolytic uraemic syndrome in children.

We thank Dr R H R White for permission to report these patients. Dr Enayat was supported by Action Rescarch. We thank Mrs P Mann for typing the manuscript.

\footnotetext{
References

' Gasser VC, Gautier, E, Steck A, Siebermann RE, Oechslin R. Hamolytisch-uramisch syndrome. Bilaterale nierenrindennekrosen bei akuten erworbenen hamolytischen anamien. Schweitz Med Wochenschr 1955;85:905-9.

2 Anonymous. Platelets, endothelium and renal disease [Editorial]. Lancet 1979;ii:890-2.

3 Fong JSC, de Chaderevian JP, Kaplan BS. Hemolytic uremic syndrome: current concepts and management. Pediatr Clin North Am 1982;29:835-56.
} 
${ }^{4}$ Webster J, Rees AJ, Lewis PJ, Hensby CN. Protacyclin deficiency in haemolytic uraemic syndrome. $\mathrm{Br}$ Med $J$ 1980;281:271.

5 Remuzzi G, Marchesi D, Mecca G, et al. Haemolytic uraemic syndrome: deficiency of plasma factor(s) regulating prostacyclin activity? Lancet 1978;ii:871-2.

${ }^{6}$ Levin M, Elkon KB, Noakes TJ, et al. Inhibitor of prostacyclin production in sporadic haemolytic uraemic syndrome. Arch Dis Child 1983;58:703-8.

${ }^{7}$ Fujimoto T, Ohara S, Haviger J. Thrombin induced exposure and prostacyclin inhibition of the receptor of factor VIII/von Willebrand factor in human platelets. J Clin Invest 1982;69:1212-22.

${ }^{8}$ Bloom AL. The von Willebrand syndrome. Semin Hematol 1980;17:215-27.

9 Ruggeri ZM, Zimmerman TS. The complex multimeric composition of factor VIII/von Willebrand factor. Blood 1981;57:1140-3.

10 Brain MC, Neame PB. Thrombotic thrombocytopenic purpura and the haemolytic uraemic syndrome. Semin Thromb Hemost 1982;8:186-97.

1 Moake JL, Rudy CK, Troll JH, et al. Unusually large plasma factor VIII: von Willebrand factor multimers in chronic relapsing thrombotic thrombocytopenic purpura. $N$ Engl $J$ Med 1982;307:1432-5.

12 Sanchez AJ, Vitacco M, Molinas F, et al. Coagulation studies in the haemolytic uraemic syndrome. J Pediatr 1972;76:538-48.

13 Appiani AC, Edefonti A, Bettinali A, et al. The relationship between plasma levels of the factor VIII complex and platelet release products (B-thromboglobulin and platelet factor 4 ) in children with the hemolytic uraemic syndrome. Clin Nephrol 1982;17:195-9.
${ }^{14}$ Moake J, Byrnes J, Rudy C, et al. Factor VIII: von Willebrand factor antigen level and multimer patterns in the hemolytic uremic syndrome. Clinical Research 1983;31:484.

15 Short PE, Williams CE, Picken AM, Hill FGH. Factor VIII related antigen: an improved enzyme immunoassay. Med Lab Sci 1982;39:351-5.

${ }^{16}$ Brinkhous KM. Read MS. Preservation of platelet receptors for platelet aggregating factor/von Willebrand factor by air drying, freezing and lyophilisation: new stable platelet preparations for von Willebrand factor assays. Thromb Res 1978;13:591-7.

17 Enayat MS, Hill FGH. Qualitative VIIIR:AG function screening of multiple samples by two-dimensional crossed immunoclectrophoretic technique. Med Lab Sci 1982;39:357-62.

18 Enayat MS, Hill FGH. Analysis of the complexity of the multimeric structure of factor VIII related antigen/von Willebrand protein using a modified electrophoretic technique. J Clin Pathol 1983;36:915-9.

${ }^{19}$ Marcus AJ. Moschcowitz revisited. $N$ Engl J Med 1982;307: 1447-8.

20) Lian EC-Y, Savaraj N. Effects of platelet inhibitors on the platelet aggregation induced by plasma from patients with thrombotic thrombocytopenic purpura. Blood 1981;58:354-9.

21 Jaffe EA. Endothelial cells and the biology of factor VIII. $N$ Engl J Med 1977;296:377-83.

22 Hoyer JR, Michael AF, Hoyer LW. Immunofluorescent localisation of antihaemophiliac factor antigen and fibrinogen in renal diseases. J Clin Invest 1974;53:1375-84.

Correspondence to Dr P E Rose. Children's Hospital, Ladywood Middleway, Birmingham B16 8ET.

Received 16 August 1984 